\title{
Implementasi Dakwah dalam Menanamkan Nilai-nilai Pendidikan Islam untuk Membina Kepribadian Sehat
}

\author{
Dewi Sa'diyah \\ UIN Sunan Gunung Djati Bandung \\ E-mail: dewisdiah@gmail.com
}

\begin{abstract}
This study show that goals and method in order to build healthy character refer to vision and mission of Faculty of Da'wah and Communications. The Development of faitful individuals with beliefs in One Suprema God and healty personal characters and with the following indicators: proper religious teachings, good worship, healthy personality, good social skills, critical thinking, and active participation in organizing and developing religious activities at campus level. All those programs should be well managed, and this study has successfully constructed a implementation da'wah for students' healthy character building at campus. The present study has made an important contribution to the vision and mission of Communications and Islam Broadcasting to create ulul albab human kind.
\end{abstract}

\section{Kata Kunci:}

Dakwah, Pendidikan, Membina, dan Kepribadian Sehat

\section{A. Pendahuluan}

Penerapan kata dakwah biasanya mengajak kepada ajaran Islam yang kaffah. Bahasa Arab دعوةdakwah bermakna secara kebahasaan dakwah adalah kata dasar (masdar) dari kata kerja da'a-yad'u yang berarti panggilan, seruan atau ajakan. Dakwah adalah setiap kegiatan yang bersifat menyeru, mengajak, dan memanggil orang untuk beriman dan taat kepada Allah Swt., sesuai dengan garis akidah, syariat, dan akhlak Islamiyah. Sedangkan tujuan utama dakwah ialah mewujudkan kebahagiaan dan kesejahteraan hidup di dunia dan di akhirat yang diridhai oleh Allah Swt., yakni dengan menyampaikan nilai-nilai yang 
dapat mendatangkan kebahagiaan dan kesejahteraan yang diridhai oleh Allah SWT., sesuai dengan segi atau bidangnya masing-masing (Ensiklopedi Islam,1994: 280).

Implementasi dakwah dalam menanamkan nilai-nilai pendidikan Islam apabila dikaitkan dengan fenomena masyarakat Indonesia di kalangan remaja sekarang ini mengalami krisis moral, sehingga perlu pembenahan terutama di dunia pendidikan dan implementasinya. Dakwah yang bernilai pendidikan bertujuan untuk mengembangkan kepribadian sehat yang dimiliki manusia secara utuh dan menyeluruh. Orang-orang dengan kepribadian yang sehat dapat menyesuaikan dirinya dengan baik dan dapat mengaktualisasikan dirinya (self actualizing).

Jadi, implementasi dakwah yang dimaksud dalam penelitian ini yaitu pelaksanaan kegiatan menanamkan nilai-nilai pendidikan Islam untuk membina kepribadian sehat melalui; tauhid, iman, Islam ihsan takwa, ikhlas, tawakkal, syukur, dan sabar. Pandangan Antonio (2007:187-193) bahwa tuntunan Muhammad Saw tentang sifat-sifat guru yang menjadi indikator kepribadian sehat yaitu : Ikhlas, jujur, adil, akhlak mulia, tawadhu, berani, jiwa humor yang sehat, sabar dan menahan amarah, menjaga lisan, sinergi dan musyawarah. Kejadian yang sering muncul dalam tindakan mahasiswa, yang bertolak belakang dengan nilai dakwah dalam menanamkan membina kepribadian sehat yang dididikkan, seperti timbulnya pergeseran nilai bagi peserta didik menimbulkan persoalan tersendiri yang mengakibatkan munculnya gejala-gejala yang tidak diharapkan. Oleh karena itu, guna menghindari semakin rusaknya komitmen berkepribadian sehat, maka bagaimana implementasi dakwah dalam menanamkan nilai-nilai pendidikan Islam untuk membina kepribadian sehat yang bisa diterapkan di Fakultas Dakwah dan Komunikasi.

Penelitian ini menggunakan metode deskriptif dengan pendekatan kualitatif. Subyek penelitian yang dimaksudkan di sini adalah respondennya 8 Dosen dan 16 mahasiswa KPI semester VI dan VII 2012-2013 pada Fakultas Dakwah dan Komunikasi UIN SGD Bandung. Sedangkan teknik pengumpulan data yang digunakan dalam penelitian ini adalah: Observasi, wawancara mendalam, studi dokumentasi, dan studi pustaka. Data dianalisis melalui: reduksi data, 
display data, penarikan kesimpulan dan verifikasi (Milles \& Huberman, 1992: 16-19).

\section{B. Kerangka Teori}

\section{Implementasi Dakwah}

Implementasi adalah pelaksanaan; penerapan; pertemuan kedua ini bermaksud mencari bentuk tentang yang disepakati, (Departemen Pendidikan Nasional, 2001:427). Dakwah merupakan mengajak, menyeru, memanggil, suruan, permohonan dan permintaan. Istilah itu sering diberi arti yang sama dengan istilah-istilah tabligh, 'amar ma'ruf dan nahi munkar, mau'izah hasanah, tabsyir, indzar, washiyah, tarbiyah, ta'lim dan khutbah. Dalam praktiknya selain istilah-istilah itu sudah merupakan muatan dakwah juga sama-sama melibatkan tiga unsur, yaitu penyampai pesan, informasi yang disampaikan dan penerima pesan. Tetapi dakwah mengandung pengertian yang lebih luas dari istilah-istilah yang dimaksud, karena istilah dakwah mengandung makna sebagai aktivitas menyampaikan ajaran Islam, menyuruh berbuat baik dan mencegah perbuatan munkar, berisi ajaran yang baik, memeberi kabar gembira dan peringatan, pendidikan, pengajaran dan pidato. Secara terminologis dakwah adalah ajakan kepada kebaikan dan keselamatan. Dakwah sebagai seruan atau ajakan kepada keinsyafan, atau usaha mengubah situasi kepada situasi yang lebih baik dan sempurna baik terhadap pribadi maupun masyarakat. Dari definisi ini tampah bahwa esensi dakwah merupakan aktivitas dan upaya untuk merubah manusia, baik individu maupun kolektif, dari situasi yang tidak baik kepada situasi yang lebih baik (Shihab, 1992).

Pesan dakwah berisi penyampaian informasi ajaran Islam berupa ajakan berbuat baik dan larangan berbuat kemungkaran. Semua itu berfungsi sebagai kontrol sosial, koreksi terhadap pemahaman ajaran agama yang tidak benar, sikap dan tingkah laku menyimpang. Maka, tujuan dakwah dapat diklasifikasikan ke dalam tujuan urgen dan insidental. Tujuan urgen adalah mengatasi permasalahan-permasalahan penting dan rumit yang dihadapi umat, yaitu permasalahanpermasalahan yang menghambat terwujudnya masyarakat yang saleh baik individual maupun sosial. Sedangkan tujuan insidental adalah 
memecahkan masalah-masalah yang terjadi sewaktu-waktu dalam masyarakat seperti pemahaman ajaran agama yang tidak benar.

Dari uraian di atas, sebagai relevansi dakwah adalah solusi atas problematika umat. Relevansi itu semakin signifikan apabila dakwah dilakukan secara profesional dan proporsional, dapat menyeluruh semua lapisan masyarakat. Artinya, dakwah harus dikemas sedemikian rupa untuk mempengaruhi persepsi masyarakat bahwa nilai-nilai ajaran Islam lebih tinggi nilainya dari nilai-nilai yang lain sehingga dakwah harus dapat menampilkan Islam sebagai Rahmatan lil al-'alamin. Sementara Syukir (1983:27) berpandangan bahwa berdakwah dengan segala bentuknya adalah wajib bagi setiap muslim. Ini semua berarti bahwa syariat Islam menekankan pentingnya usaha yang optimal sesuai dengan kemampuannya.

\section{Peranan Dosen dalam Menanamkan Nilai-nilai Pendidikan Islam untuk Membina Kepribadian Sehat}

Berkenaan dengan peranan Dosen dalam mengkomunikasikan nilai-nilai dakwah dalam membina kepribadian sehat acuannya adalah Undang-Undang Nomor 20 Tahun 2003 tentang Sistem Pendidikan Nasional pada Bab XI mengenai tenaga pendidikan dan tenaga kependidikan pada Pasal 29 ayat (2) dijelaskan, bahwa pendidikan dan tenaga kependidikan berkewajiban sebagai berikut : "Menciptakan suasana pendidikan yang bermakna, menyenangkan, kreatif, dinamis, dan dialogis; Mempunyai komitmen secara profesional untuk meningkatkan mutu pendidikan; memberi teladan dan menjaga nama baik lembaga, profesi, dan kedudukan sesuai dengan kepercayaan yang diberikan kepadanya". Keberadaan dosen di kampus dalam proses mengkomunikasikan dakwah yang ditujukan untuk menciptakan kepribadian sehat, para mahasiswa menjadi manusia yang shaleh dipandang sebagai bagian terpenting dalam percaturan pendidikan persekolahan. Berbagai studi membuktikan bahwa pengaruh dosen atau guru terhadap perkembangan kepribadian sehat merupakan faktor penentu.

Kepribadian sehat pandangan Hurlock (1974:423) has defined : People with healthy personalities are those who are judged to be well adjusted. They are so judged because they are able to function efficiently in the word of people. They experience a kind of "inner harmony" in the 
sense that they are at peace with other as well as with themselves. Orang yang mempunyai kepribadian sehat adalah orang yang dinilai mampu sebagai seseorang yang dapat menyesuaikan diri dengan baik. Mereka dinilai demikian, karena mereka dapat berfungsi dan bekerja secara efektif di dunia masyarakat. Mereka mempunyai pengalaman seperti : inner harmony (keharmonisan dari dalam) di mana mereka berada dalam keadaan damai dengan orang lain, begitu juga damai dari dalam diri mereka sendiri. Sedangkan kondisi kepribadian sehat menurut Usman Najati (2005:379) mengistilahkan dengan kepribadian normal menurut Islam ialah kepribadian yang berimbang antara tubuh dan roh serta memuaskan kebutuhan-kebutuhan, baik untuk tubuh maupun roh. Dalam waktu yang bersamaan, juga berpegang teguh pada keimanan kepada Allah Swt., menunaikan peribadahan, menjalankan segala apa yang diridhai-Nya dan menghindari semua hal yang dapat mengundang murka-Nya. Jadi, pribadi yang dikendalikan hawa nafsu dan syahwatnya adalah pribadi yang normal atau sehat. Faktor utama dalam penilaian suatu kepribadian, dalam pandangan Al-Quran, adalah akidah dan ketakwaan, sesuai Q. S. Al-Hujuraat/49:13. Sementara karakteristik kepribadian sehat (healthy personality) pandangan Hurlock (1974:425) adalah ditandai dengan : "(1) Mampu menilai diri secara realistik, (2) Menilai situasi secara realistik, (3) Menilai prestasi yang diperoleh secara realistik, (4) Menerima tanggung jawab, (5) Kemandirian (autonomy), (6) Dapat mengontrol emosi, (7) Berorientasi tujuan, (8) Berorientasi keluar, (9) Penerimaan sosial, (10) Memiliki filsafat hidup, dan (11) Berbahagia."

Maka implementasi dakwah dalam membina kepribadian sehat dapat terlaksana secara efektif, apabila dosen berperan sebagai dirinya sendiri, dan sebagai orang tua. Dia harus mampu menampilkan kepribadian sehat yang patut ditiru dan diteladani oleh anak didiknya. Di sisi lain, dosen harus mencurahkan perhatiannya seperti, orang tua kepada anaknya sendiri. Khususnya di kampus agar benar-benar terinternalisasi, sehingga terwujudnya pribadi-pribadi peserta didik yang sehat, shaleh, beriman dan bertakwa kepada Allah Swt. Mengingat perkembangan diri remaja menjelang dewasa seperti yang telah diketengahkan terdahulu suatu pendekatan persuasif baik dalam ucapan dan tindakan serta menyampaikan ajaran-ajaran Islam akan 
lebih mengena pada kebutuhan perkembangan moralitas dan membekas dalam diri peserta didik (An-Nahlawi, 1992: 32).

Mengingat disatu pihak peranan dosen dalam menanamkan nilainilai pendidikan Islam sebagai implementasi dakwah dalam membina kepribadian sehat mahasiswa di kampus yang sedemikian pentingnya dan di lain pihak perkembangan remaja dewasa (mahasiswa) seperti telah dikemukakan terdahulu, maka peranan dosen diharuskan menguasai berbagai macam metode dalam mempengaruhinya, yaitu: (a) Keteladanan, (b) Pembiasaan, (c) Perhatian, dan (d) Nasihat.

Pendekatan dakwah yang memiliki nilai-nilai pendidikan Islam yang berkaitan dengan pola perkembangan moral dalam pendidikan ada delapan pendekatan menurut Martorella (1976:60-62) yaitu : "Evocation, inculcation, moral reasoning, value clarification, value analysis, moral awareness, commitment approach, dan union approach."

\section{Pembahasan}

\section{Tujuan Implementasi Dakwah dalam Menanamkan Nilai-nilai} Pendidikan Islam untuk Membina Kepribadian Sehat

Menyimak deskripsi tentang tujuan implementasi dakwah dalam menanamkan nilai-nilai pendidikan Islam yang diupayakan oleh dosen dalam membina kepribadian sehat atau akhlak mahasiswa di lingkungan kampus, dapat diinterpretasikan bahwa upaya dosen telah diwarnai oleh faktor-faktor internal dan faktor eksternal. Segala upaya yang dilakukan oleh dosen (ARd, Ed, dan NMd) dalam pembinaan kepribadian yang sehat, sudah mengarah kepada pencapaian satu tujuan yaitu manusia memiliki keperibadian sehat yang utuh, dalam arti keselamatan di dunia dan keselamatan di akhirat. Dalam mencapai tujuan tersebut, mereka lakukan berulang-ulang dengan penuh rasa tanggung jawab dan komitmen yang cukup kuat, walaupun dengan cara pendekatan yang berbeda dalam menampilkan perilakunya, akan tetapi tujuan tetap menjadi harapan bersama sebagai sesuatu yang ingin dicapai.

Pembinaan kepribadian sehat terhadap mahasiswa yang dilakukan oleh dosen merupakan alat untuk membantu mereka dalam melaksanakan tata cara hidup sehari-hari, yang mencakup hablum 
minallah dan hablum minannas, akhirnya tercipta kehidupan yang damai, selalu berusaha menempatkan diri dalam lingkungan baik di kampus maupun di masyarakat pada umumnya, sehingga disenangi dalam kehidupan dan pergaulan sehari-hari.

Memahami visi dan misi Fakultas Dakwah dan Komunikasi rasanya sulit untuk dipisahkan dengan pemikiran AMdf, sebagai Dekan Fakultas Dakwah dan Komunikasi, bahwa pemikiran AMdf khususnya mengenai misi memang banyak diilhami oleh pemikiran bahwa mempunyai komitmen yang tinggi untuk melahirkan generasi bangsa yang berkualitas dan mampu bersaing. Berbagai hambatan dan rintangan tidak akan menyurutkan langkah Fakultas Dakwah dan Komunikasi dalam menciptakan generasi khairu ummah. Generasi terbaik yang bertafaqquh fiddin dan berakhlaq alkarimah. Generasi yang mampu memberikan manfaat bagi umat muslimin secara keseluruhan.

Dalam penelitian ini, terungkap tujuan ideal dan riil maka tujuan implementasi dakwah dalam menanamkan nilai-nilai pendidikan Islam untuk membina kepribadian sehat ingin dicapai oleh dosen diimplementasikan dalam wujud ucapan, pikiran, dan tindakan yang mampu merefleksikan diri mereka sebagai wujud pribadi sehat atau muslim yang kaffah, terutama mewujudkan agar semua mahasiswa Fakultas Dakwah dan Komunikasi khususnya Jurusan KPI memiliki kepribadian sehat dan akhlak yang terpuji. Akhlak pada dasarnya adalah akumulasi dari nilai-nilai dasar yang dihayati mahasiswa, yang diajarkan dosen di lingkungan kampus, dan dapat diungkap dalam tutur kata yang sopan dan tingkah laku yang sesuai dengan tata nilai lembaga atau kampus. Daradjat (1984:255) sebagai konsistensi perilaku yang merupakan dampak dari keyakinan dan ritual keagamaan. Sifat-sifat yang harus dimiliki guru atau dosen dalam pendidikan Islam yaitu: Zuhud tidak mengutamakan materi mengajar karena mencari keridhaan Allah semata, kebersihan guru, ikhlas, pemaaf, seorang guru merupakan seorang bapak sebelum ia seorang guru, harus mengetahui tabiat murid, harus menguasai mata pelajaran (Al-Abrasyi, 2003:146-149). Sedangkan menurut AMd dan Ed, dengan menyadari potensi yang dimiliki manusia, Fakultas Dakwah dan Komunikasi yang berusaha untuk memaksimalkan potensi mahasiswa dan membimbingnya, agar menjadi anak yang shaleh, sholehah, dan insan yang sehat dicintai Allah 
Swt.

Tujuan implementasi dakwah dalam menanamkan nilai-nilai pendidikan Islam ini, terkandung dalam perilaku dosen praktik ibadah ketika mengajak atau menganjurkan mahasiswa untuk melaksanakan shalat berjamaah tepat waktu, bimbingan baca tulis Al-Quran lengkap dengan penafsirannya secara sungguh-sungguh, dan bimbingan tahfid minimal 1 juz. Makna yang terkandung dari aktivitas atau kegiatan dosen dan mahasiswa tersebut, adalah makna nilai ketaatan, nilai kesungguhan, dan nilai kejujuran. Nilai tersebut terungkap pada saat mngucapkan dan melakukan bacaan yang sudah diatur dan dicontohkan dalam shalat. Untuk menyatakan kesungguhan dalam shalat perlu adanya pengucapan bacaan shalat yang benar, penghayatan, menghadirkan Allah dalam perasaan sedang shalat seolah-olah nampak berhadapan sedang memperhatikan, menurut Al-Ghazali jilid II (tt:157) "Adalah dengan menolak pikiran-pikiran yang datang dari luar atau dalam dirinya." Sebagaimana yang diungkapkan Daradjat (1984:199), makna shalat dalam hidup seorang muslim sebagai suatu ciri penting bagi orang bertakwa, orang berbahagia, dan berperan untuk menjauhkan diri dari pekerjaan jahat dan mungkar.

Dalam kaitannya dengan hubungan sesama manusia, tercermin pada perilaku mahasiswa terutama ketaatan kepada Allah Swt., dalam bentuk pelaksanaan dan kewajiban dalam berbagai jenis pembinaan dan pembiasaan yang diberikan oleh para dosen praktik ibadah (mengurus jenazah dan praktik ibadah haji) dan praktik tilawah. Di antaranya melaksanakan tugas membuat naskah ceramah atau pidato, tahfidz 1 juz, hafalan do'a-do'a, dianjurkan ceramah bergiliran yang dilakukan oleh para mahasiswa di akhir pertemuan praktik ibadah, dan lainnya. Hal tersebut mengandung makna tujuan implementasi dakwah dalam menanamkan nilai-nilai pendidikan Islam untuk membina kepribadian sehat mahasiswa yaitu terciptanya hidup berdisiplin terhadap waktu dan tugas, baik di kampus maupun dalam keluarga, dan sebagai nilai tanggung jawab. Dosen mengupayakan agar visi dan misi Fakultas Dakwah dan Komunikasi dapat disosialisasikan dalam berbagai kegiatan kampus, yang telah mampu meletakan landasan filosofis pendidikannya sebagai berikut:

1) Manusia memiliki potensi yang tidak terbatas dan hanya 
memanfaatkan sebagian kecil saja dari seluruh potensi yang dimiliki manusia sedangkan pendidikan harus mampu memaksimalkan potensinya untuk kemaslahatan umat manusia;

2) Pendidik dan yang dididik adalah mitra harus terjalin hubungan yang baik atau harmonis, hubungan di antara keduanya bukan hubungan manipulatif yakni dosen membentuk mahasiswa sekehendak hatinya. Keduanya terlibat dalam hubungan cinta yang transformatif, sehingga dalam proses ini keduanya berubah makin lama makin baik dan mencapai tujuan yang diinginkan;

3) Pendidik dan yang dididik merupakan upaya merealisasikan asma Allah dalam diri manusia. Dalam Islam hidup adalah perjalanan panjang dari tanah menuju ruh-Nya, dari kegelapan menuju cahaya, dari makhluk menuju Khaliq. Dalam perjalanan ruhani ini, kita harus menyerap nama-nama Allah.

4) Implementasi dakwah yang bernilai pendidikan adalah perubahan manusia seutuhnya dan perubahan eksistensial. Pendidikan harus melibatkan tubuh dan jiwa sekaligus. Hal-hal yang bersifat fisikal berpengaruh besar pada konsep psikologis seperti ; persepsi, kognitif, konsep diri, dan sebagainya.

b. Metode yang Dilakukan oleh Dosen dalam Menanamkan Nilai-nilai Pendidikan Islam untuk Membina Kepribadian Sehat

Pada bagian ini, data hasil penelitian diketengahkan secara rinci, kemudian dianalisis untuk menemukan makna substansinya sebagai upaya atau metode dosen dalam menanamkan nilai-nilai pendidikan Islam untuk membina kepribadian sehat mahasiswa. Oleh karena itu, proses metode yang dilakukan oleh dosen melalui metode internalisasi yang memiliki 3 tujuan pembelajaran yaitu ; tahu, mengetahui (knowing), mampu melaksanakan atau mengerjakan yang ia ketahui (doing), dan mahasiswa menjadi orang seperti yang ia ketahui itu, konsep itu seharusnya tidak sekedar menjadi miliknya tetapi menjadi satu dengan kepribadiannya (aspek being), sehingga metode belum dapat digunakan bila tidak dikuasai tekniknya (Tafsir, 2006: 226-229). Maka, penulis meminjam pemikirannya Tafsir yaitu menggunakan metode internalisasi dengan teknik pembelajarannya yang ada di 
lingkungan Fakultas Dakwah dan Komunikasi UIN SGD Bandung yaitu : (1) Keteladanan; (2) Mauidhah Hasanah atau Nasihat yang Baik; (3) Perhatian; (4) Riyadhah melalui Pembiasaan. Proses pendidikan lebih banyak terletak pada level metode internalisasi dengan teknik keteladanan, nasihat yang baik, perhatian, dan pembiasaan yang dilakukan oleh para dosen untuk mempengaruhi mahasiswa dalam membina kepribadian sehat adalah dengan penampilan para dosen sebagai sosok yang patut diteladani. Dalam deskripsi di atas, terkandung makna bahwa perilaku mereka tidak semata-mata terikat oleh aturan formal. Dosen praktik ibadah, praktik tilawah, dan dosen lainnya serta tokoh-tokoh yang sukses selalu berusaha memiliki nilai etik dan estetik, yang di dalammnya terkandung bagian yang tak terpisahkan dalam dirinya (personalized). Mereka secara tidak langsung telah membimbing mahasiswa dalam mengaplikasikan implementasi dakwah dalam menanamkan nilai-nilai pendidikan Islam untuk membina kepribadian sehat melalui; metode bil hikmah, mauizhah hasanah, keteladanan, perhatian, penugasan, dan pembiasaan. Contoh "Pembelajaran Shalat", ada tiga tujuan pembelajaran shalat menurut Tafsir (2006:226-227) yaitu : (1) Tahu konsep shalat, (2) Terampil melaksanakan shalat (doing), (3) Peserta didik melaksanakan shalat dalam kehidupannya sehari-hari (being). Kegiatan dalam proses pendidikan yang dilakukan oleh dosen terhadap mahasiswa baik niat, ucap, perilaku, dan tindakan dapat direalisasikan dalam kehidupan sehari-hari dalam bentuk ketaatan dan beribadah kepada Allah, mematuhi peraturan lembaga, belajar diskusi, keindahan penataan fisik kampus, kebersamaan (diskusi kelompok), kemandirian, peningkatan ilmu pengetahuan dan keterampilan, dan penampilan berpakaian, yang demikian itu mereka lakukan agar dapat membiasakan mahasiswa melakukan hal-hal yang baik. Adapun teknik keteladanan yang mereka lakukan selalu disesuaikan dengan konteksnya misalnya, pada saat istirahat sebagian dosen dan mahasiswa melaksanakan shalat berjamaah Dzuhur dan Ashar di masjid, sambil mendengarkan ceramah 10 menit yang dilaksanakan oleh para dosen secara bergiliran. Selain itu memperlihatkan pula bahwa para dosen berusaha untuk melaksanakan tugas dan kewajiban sebagai pembimbing, pengarah, penasehat, dan pembina terhadap mahasiswa yang memerlukan bimbingan dan 
penyadaran dirinya.

Sementara metode yang diturunkan ke dalam teknik yang dilakukan dosen melalui mauidhah hasanah atau nasihat yang baik untuk mempengaruhi mahasiswa menjadi manusia yang memiliki berkepribadian sehat, ternyata dilakukan tidak hanya terbatas dalam konteks rutinitas kegiatan yang sudah berlabelkan agama saja, akan tetapi dilakukan juga pada setiap kesempatan dalam segala bentuk kegiatan kehidupan baik dalam situasi formal di kelas, di masjid dan kampus atau di luar kelas. Dalam mempertahankan nilai-nilai religius mahasiswa di kampus, melalui mauidhah hasanah ternyata dilakukan secara menyeluruh di antaranya : Mencakup seluruh kondisi kehidupan, aneka peristiwa alam semesta, dan fenomena-fenomena kekuasaan serta karunia Allah Swt. Dosen (ARd) terbiasa memberikan nasihat diselingi dengan humor dan tanya jawab, ketika melihat mahasiswanya merasa jenuh dengan mata kuliah yang banyak tugas-tugasnya, atau memberikan solusi terhadap mahasiswanya agar tugas-tugasnya jangan sampai ditumpuk tetapi dikerjakan selalu tepat waktu terus dituntut di kerjakan akhirnya tidak merasa beban menghadapi banyak tugas dari dosen yang bersangkutan.

Perhatian dosen dengan cara melontarkan pertanyaanpertanyaan kepada mahasiswa tidak hanya bermakna komunikasi lisan semata, akan tetapi mengandung makna yang lebih penting yaitu adanya perhatian dan kepedulian dosen yang sangat mendasar mengingatkan kembali kepada mahasiswa akan tugas-tugas yang mereka emban sebagai mahasiswa. Dengan bertanya, dosen telah mengingatkan mahasiswa agar mengetahui apa yang menjadi permasalahan yang sedang dihadapi, sehingga dapat membantu mengatasinya. Atas dasar perhatian dan pemahaman terhadap keadaan dan latar belakang yang menjadi persoalan mahasiswa, tindakan para dosen akan lebih terarah dan tepat sasarannya dalam memecahkan persoalan yang dimiliki mahasiswa. Melalui perhatian berarti para dosen telah saling mewasiati, mengingatkan, dan menaati suatu kebenaran yang merupakan wujud kepedulian sosok manusia yang berkepribadian sehat.

Dengan berbagai kegiatan yang dilakukan dosen, baik dalam konteksnya yang berkenaan langsung dengan nilai-nilai akhlak 
mahasiswa yang baik, cara mengkaitkannya dengan nilai-nilai akhlak terhadap Allah, akhlak terhadap manusia dan lingkungannya, jelas memperlihatkan bahwa pembiasaan yang dilakukan dosen sangat mempengaruhi pertumbuhan perilaku mahasiswa untuk berakhlak yang lebih baik dan memiliki kepribadian yang sehat. Dalam situasi seperti tersebut di atas, pembiasaan yang dilakukan dosen akan menjadi titik awal perbuatan mahasiswa untuk lebih meningkatkan: Ketaatan terhadap Allah, peningkatan pengetahuan, kemandirian, disiplin dalam berbagai kegiatan walaupun dirasa belum maksimal dalam menanganinya.

\section{Penutup}

Implementasi dakwah dalam menanamkan nilai-nilai pendidikan Islam untuk membina kepribadian sehat di lingkungan kampus adalah agar para maasiswa menjadi insan yang sehat, beriman dan bertakwa kepada Alla Swt., untuk mencapai keselamatan dunia dan akhirat, searah dengan visi \& misi Fakultas Dakwah dan Komunikasi, serta direalisasikan dalam bentuk ketaatan kepada Allah Swt., disiplin, jujur, sabar, kasih sayang, ikhlas, dan pemaaf. Metode yang dilakukan dosen dalam menanamkan nilai-nilai Islam untuk membina kepribadian sehat melalui berbagai metode yaitu; keteladanan, mauidhah hasanah atau nasihat yang baik, perhatian, kasih sayang, penugasan, dan riyadhah serta teknik lainnya. Dengan metode yang sangat menarik akan menyentuh perasaan mahasiswa dalam mencapai tujuan dakwah dalam menanamkan nilai-nilai pendidikan Islam untuk membina kepribadian sehat, sehingga menjadi motivasi dalam diri mahasiswa untuk mengikuti perkuliahan secara benar, ikhlas, dan sungguh-sungguh.[] 


\section{DAFTAR PUSTAKA}

Al-Abrasyi, A. 2003. Prinsif-prinsif Dasar Pendidikan Islam: Diterjemahkan dari At-Tarbiyah Al-Islamiyyah. Bandung: Pustaka Setia.

Al-Ghazali. tt. Ihya' Ulumiddin. Beirut : Dar al-Fikr.

An-Nahlawi, A. (1992). Pendidikan Islam di Rumah, Sekolah, dan Masyarakat, Terjemahan Shihabudin. Jakarta: Gema Insani Press.

Antonio, M. S. 2007. Muhammad Saw The Super Leader Super Manager. Jakarta: Prophetic Leadership \& Management Centre.

Daradjat, Z. 1984. Dasar-dasar Agama Islam: Buku Teks Pendidikan Agama Islam pada Perguruan Tinggi Umum. Jakarta : Bulan Bintang.

Departemen Pendidikan Nasional. 2001. Kamus Besar Bahasa Indonesia. Jakarta: Balai Pustaka.

Ensiklopedi Islam. 1994. Cet. 3. Jilid 5. Jakarta: Ichtiar Baru Van Hoeve.

Hurlock, B.E. 1974. Personality Development. New York: McGraw-Hill Book Company.

Martorella, P. P. 1976. Social Strategies Theory into Practice. London: Harper and Row Publ. Co.

Milles, M.B. \& Huberman, A.M. 1984. Qualitative Data Analysis. Sage Publication Inc.

Najati, M.U. 2005. Psikologi dalam Al-Quran : Terapi Qurani dalam Penyembuhan Gangguan Kejiwaan. Bandung: Pustaka Setia.

Quraish, S. M. 1992. Membumikan Al-Quran. Bandung: Mizan.

Syukir, Asmuni. 1993. Dasar-dasar Strategi Dakwah Islam. Surabaya: AlIkhlas.

Tafsir, A. 2006. Filsafat Pendidikan Islam. Bandung: Remaja Rosdakarya.

Talsya, T., A.B. 1973. Adat Resam Aceh. Banda: Pustaka Meutia.

Ulwan, A.N. 1992. Kaidah-kaidah Dasar Pendidikan Anak Menurut Islam. Penerjemah K.A. Manyukur Hakim. Bandung: Rosdakarya.

Undang-Undang RI. No. 20 Tahun 2003. Tentang Sistem Pendidikan Nasional. Bandung: Fokusmedia. 